\title{
A Rare Case Report on Thoracoomphalopagus
}

\section{Lamichhane $\mathbf{S}^{1}$, Banerjee $\mathbf{B}^{2}$, Subedi $\mathbf{S}^{3}$}

${ }^{1}$ Lecturer, ${ }^{2}$ Professor, ${ }^{3}$ Assistant professor, Department of Obstetrics and Gynaecology, Nobel Medical College Teaching Hospital, Biratnagar, Nepal

Received: December 12, 2015 ; Accepted: February 22, 2016

In a present case study we are reporting a case of thoracoomphalopagus conjoined twins. A 24 years old gravida two para $0+1$ carrying thoracoomphalopagus conjoined twins was diagnosed by ultrasonography at early second trimester with single placenta attached posteriorly and low lying. The mortality and morbidity of conjoined twins are high so making the early diagnosis with ultrasonographic examination provides the parents a chance to elect for pregnancy termination.

Keywords: conjoined; outcome; twins

\section{INTRODUCTION}

Conjoined twins represent one of the rarest forms of twin gestation, incidence ranges from 1 in 50,000 to 1 in 100000 live births. ${ }^{1}$ If twinning is initiated after eight days of fertilization conjoined twins result. ${ }^{2}$ Approximately $40 \%$ of conjoined twins arrive stillborn, and about $35 \%$ survive only one day. ${ }^{3}$ The overall survival rate of conjoined twins is around $5 \%{ }^{4}$ Classification is usually done according to most prominent site of connection: Thoracopagus joined at thorax (19\%), Omphalopagus, joined at anterior abdominal wall (18\%), Ischiopagus joined at ischium (11\%), Craniopagus joined at head (11\%), Pyopagus joined at buttocks(6\%), Rachipagus joined at spine $(2 \%){ }^{5}$

We report a rare case of conjoined twins with thoraco-omphalopagus which presented recently in our department.

\section{CASE:}

Twenty three years old lady gravida 2 para 0 abortion 1 presented to our hospital with a history of amenorrhea for 3 months and had one episode of bleeding per vaginum at 8 weeks period of gestation and ultrasonography at that time showed singleton live fetus of 9 weeks 3 days with subchorionic hematoma for which conservative treatment was done outside. During her follow up visit, ultrasonography

\section{CORRESPONDENCE}

Dr Sabina Lamichhane

Department of Obstetrics and Gynaecology

Nobel Medical College Teaching Hospital, Biratnagar, Nepal

Email: sabina525475@gmail.com detected 13 weeks live pregnancy with thoracoomphalopagus with low lying placenta. Her history was not relevant in relation to multiple gestations. On examination her vitals were stable and her fundal height corresponding to 16 weeks size and she was counseled for termination of pregnancy as the fetal prognosis was not good. Finally termination was done with tab. Mifepristone $200 \mathrm{mg}$ per orally followed by $800 \mathrm{mcg}$ of misoprostol was placed per vaginally after 24 hours. She then expelled the fetus, thoracoomphalopagus on the same day but the placenta was not expelled so misoprostol was repeated and check curettage was done under iv antibiotics coverage. She was then discharged with no further complication.

Conjoined Twin showing attachment at the level of thorax and abdominal wall

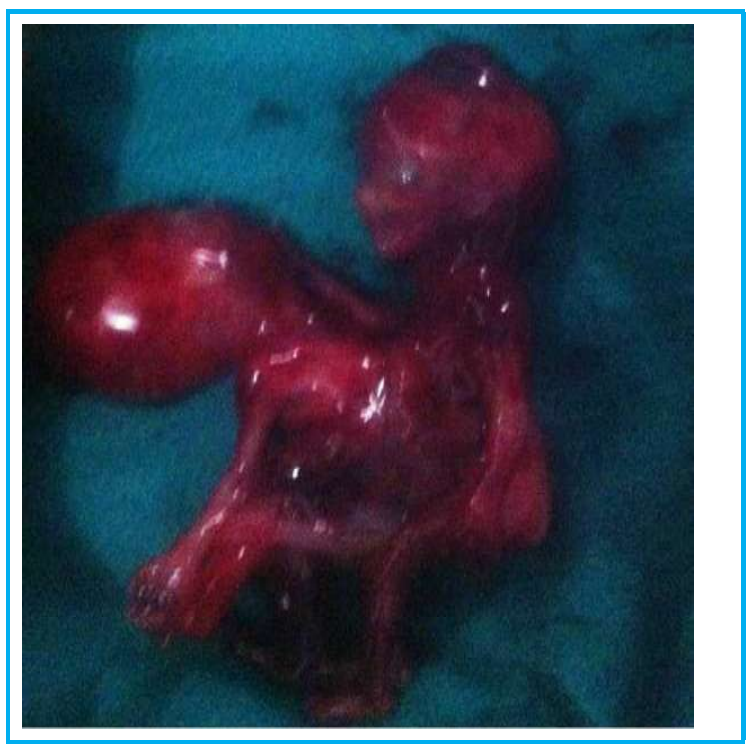




\section{COMMENT}

Conjoined twins occur with a frequency of about 1 per 50,000 deliveries and are an extremely rare complication of monochorionic twining. The precise etiology of conjoined twinning is unknown, but the most widely accepted theory is that incomplete division of monozygotic embryo occurs at approximately 13-15 days postovulation. ${ }^{6}$ Most conjoined twins are female, with ratio of women to men being reported as $3: 1$ ? $^{7}$

Aneja et $\mathrm{al}^{8}$ reported that conjoined twin with thoracoomphalopagus at 24 weeks of gestation delivered with both male with apgar 0,0 which was unusual in case of conjoined twins.

Many of these foeti are delivered prematurely and are stillborn. They are classified according to their site of union. The most common location is the chest (thoracopagus) 19\%, followed by the omphalopagus, pyopagus, ischiopagus and the craniopagus. ${ }^{9}$

Organs may be shared to varying degrees in different sets of twins. Major congenital anomalies of one or both twins are not uncommon. Antenatal diagnosis by ultasonography is possible in modern day obstetrics. Ultrasonographic identification of any of the following classical signs may suggest the diagnosis: Both fetal heads are in the same plane, twin face each other, thoracic cage are in unsual proximity, both the fetal heads are hyper-extended, no change in the relative position after maternal movement and manual manipulation in repeat examination obtained hours or days later. ${ }^{10}$

Early diagnosis of conjoined twins was previously reported, but not before 10 weeks of gestation. ${ }^{11}$

MehmetA et $\mathrm{al}^{12}$ had reported a case of conjoined twin at 11 weeks of gestation, underwent termination of pregnancy.
Grutter $\mathrm{F}$ et al ${ }^{13}$ report a case of thoracopagus fetus, ultrasonographic diagnosis at 16weeks of gestation.

On careful transvaginal sonography $b$ band serial scanning, there appears to be an inability to separate between the anatomical parts of the fetuses. Once conjoined twins have been diagnosed, characterization of the type and severity of the abnormality can be performed with ultrasonography, three-diamensional ultrasound, computed tomography, or magnetic resonance imaging. ${ }^{14,15}$

Termination of pregnancy can be offered to the family if conjoined twins are diagnosed. In the present study, diagnosis was in the early second trimester, and because the family has chosen termination of pregnancy, further diagnostic intervention was not considered. Surgery to separate conjoined twins may range from relatively simple to extremely complex, depending on point of attachment and the internal parts that are shared. Most cases of separation are extremely risky and life-threatening.

Chiu CT et $\mathrm{al}^{16}$ had reported a case on separation of thoracopagus conjoined twins at the level of heart atrioventricular groove and liver with intestinal loops, out of which, one died 5 hour after separation and next died after 7 month post operative with sepsis.

Y. H. Lam,et $\mathrm{al}^{17}$ reported two case of conjoined twins at 11 weeks and 13 weeks of gestation with the help of ultrasonography so that both of them were terminated by using prostaglandin to prevent all the complications regarding conjoined twins and parents got the golden opportunity to elect for termination of the pregnancy. Though being a rare occurrence, it carries a high incidence of perinatal mortality and even if surgery is conducted prognosis is guarded thus earlier detection and elective termination of conjoined twin is justified.

\section{REFERENCES}

1. Rees AEJ, Vujanic GM, Williams WM. Epidemic of conjoined twins in Cardiff. BJOG. 1993;100: 388-91.

2. Cunningham FG. Multifetal Gestation. In: Cunningham FG, Leveno KJ, Bloom SL, Hauth JC, Dwight JR, Spong CY editors. Williams Obstetrics. 23rd ed. McGraw-Hill; 2010. p.861.

3. Sakala EP. Obstetric management of conjoined twins. Obstet Gynecol. 1986;67(Suppl 3):21S-25S.

4. Stone JL, Goodrich JT. The craniopagus malformation: classification and implications for surgical separation. Brain. 2006;129: 1084-95.
5. Echeverry CJ. Multifetal Gestatation. In: Arias F, Daftary SN, Bhide AG, editors. Practical guide to high risk Pregnancy \& Delivery. 3rd ed. India: Elsevier; 2008. p. 306.

6. Abossolo T, Dancoisne P, Tuaillon J, Orvain E, Sommer JC, Rivière JP. Early prenatal diagnosis of asymmetric cephalothoracopagus twins. J Gynecol Obstet Biol Reprod. 1994;23: 79-84

7. Abossolo T, Dancoisne P, Tuaillon J, Orvain E, Sommer JC, Rivière JP. Early prenatal diagnosis of asymmetric cephalothoracopagus twins. Journal de gynécologie, obstétrique et biologie de la reproduction. 1994;23(1):79-84.

8. Aneja A, Rajaanna DK, Reddy VN, Mayilvavaganan KR, Pujar P. Conjoined twins: a rare case of Thoracoomphalopagus. J Clin Diagn Res. 2013;7: 1471-2. 
9. Schnaufer L. Conjoined twins. In: Raffensperger JG, editor. Swenson's Pediatric Surgery.4th edition. New York, NY, USA: Appleton Century-Crofts; 1980. p 910-20.

10. Carlos J Echeverry. Multifetal Gestatation. In: Fernando Arias, Shirish N Daftary, Amarnath G Bhide, editors. Practical guide to high risk Pregnancy \& Delivery.3rd ed.India: Elsevier; 2008.p. 307

11. Hubinont C, Kollmann P, Malvaux V, Donnez J, Bernard P. First-trimester diagnosis of conjoined twins. Fetal Diagn Ther. 1997;12: 185-7.

12. Osmanagaoglu MA, Aran T, Guven S, Kart C, Ozdemir O, Bozkaya H. Thoracopagus conjoined twins: a case report. ISRN Obstet Gynecol. 2011;2011:238360.

13. Grutter F, Marguerat P, Maillard-Brignon C, De Grandi P, Pescia G. Thoracopagus fetus. Ultrasonic diagnosis at 16 weeks. J Gynecol Obstet Biol Reprod. 1989;18: 355-9.

14. Kuroda K, Kamei Y, Kozuma S, Kikuchi A, Fujii T, Unno
$\mathrm{N}$ et al. Prenatal evaluation of cephalopagus conjoined twins by means of three-dimensional ultrasound at 13 weeks of pregnancy. Ultrasound Obstet Gynecol. 2000;16: 264-66.

15. Kingston CA, McHugh K, Kumaradevan J, Kiely EM, Spitz L. Imaging in the preoperative assessment of conjoined twins. Radiographics. 2001;21: 1187-208.

16. Chiu CT, Hou SH, Lai HS, Lee PH, Lin FY, Chen WG et al. Separation of thoracopagus conjoined twins. A case report. J Cardiovasc Surg. 1994;35: 459-62.

17. Lam YH, Sin SY, Lam C, Lee CP, Tang MH, Tse HY. Prenatal sonographic diagnosis of conjoined twins in the first trimester: two case reports. Ultrasound Obstet Gynecol. 1998;11: 28991. 